\title{
Getting Along: Straight Talk from a Family Business Veteran
}

Kimberly Eddleston (Northeastern University)

KEYWORDS: Management, Conflict, Succession.

Carl Beauregard, former President of Beauregard

Equipment, (https://www.beauregardequip.com/default.htm) has worked side by side with his father and three brothers, and has 15 younger relatives who could be involved in running the business someday. Over the years he's learned a lot about getting along with siblings and the values of trust and communication.

In this interview, he shares what he's learned about harmonious relationships with both relatives and nonrelatives at his New England-based firm, which sells farm and construction equipment. Some key takeaways: Don't cross the lines of responsibility with people who do their jobs well. Talk with key employees before you launch a change. Don't show off how you're spending your money, especially during times when the company must tighten the belt. Do a lot of "management by walking around" so you get to know non-relatives in the business. And do some careful planning before a new, larger generation takes over.

Copyright @ 2022 The Authors. Entrepreneur \& Innovation Exchange is published at EIX.org. This is an open access article under the terms of the Creative Commons Attribution-NoDerivs License, which permits use and distribution in any medium, provided the original work is properly cited and 